\title{
Major variations in blood glucose levels in pediatric patients with type 1 diabetes
}

\author{
Adriana COSMESCU ${ }^{1}$, Carmen OLTEAN², Agnes BACUSCA ${ }^{1}$, Livia PETROAIE ${ }^{3}$, \\ Ana-Maria SLANINA ${ }^{1}$, Antoneta Dacia PETROAIE ${ }^{1}$ \\ ${ }^{1}$ Preventive Medicine and Interdisciplinarity Department, Faculty of Medicine, \\ "Gr.T. Popa" University of Medicine and Pharmacy, Iasi, Romania \\ 2"Sf. Maria" Pediatric Hospital, lasi, Romania \\ ${ }^{3}$ Faculty of Medicine, "Gr.T. Popa" University of Medicine and Pharmacy, lasi, Romania
}

\begin{abstract}
Type 1 diabetes is one of the most common chronic diseases in children and adolescents, with an increasing incidence globally. Major variations in serum glucose cause severe ketoacidosis and hypoglycemia, acute metabolic complications of the disease. We performed a retrospective study on a group of 119 children and adolescents with type 1 diabetes in whom only the cases with ketoacidosis and severe hypoglycemia that required emergency hospitalization were quantified. At the same time, we identified the causes and determinants of these acute complications. According to the case study, 28.6\% of patients (34 cases) presented severe hypoglycemia, the most common causes of hypoglycemia being intense physical activity without additional carbohydrate intake, delayed carbohydrate intake, and excess insulin. 15.3\% of patients (18 cases) had ketoacidosis, of which $55.55 \%$ were recurrent ketoacidosis. Ketoacidosis has been detected in patients with poor glycemic balance and poor treatment compliance by not following a diet and skipping insulin doses. Among the additional risk fac-tors, we identified age over 13 years and the age of diabetes greater than 5 years, for both acute complications.
\end{abstract}

Keywords: type 1 diabetes, child, ketoacidosis, severe hypoglycemia

\section{INTRODUCTION}

Type 1 diabetes is a chronic condition found in childhood and young adults, the pathogenic mechanism being autoimmune. In recent years, there has been a steady increase in the incidence of this disease $(1,2)$. In addition to specific degenerative complications, the course of type 1 diabetes is exacerbated by acute metabolic complications, diabetic ketoacidosis, and severe hypoglycemia.
Data from the literature report that diabetic ketoacidosis, the most serious metabolic disorder, is identified in $15 \%$ to $67 \%$ of children and adolescents at the onset of the disease (3). Although it can be found in other types of diabetes, it is specific to patients with type 1 diabetes (4). Ketoacidosis is diagnosed at a glycemia $>11 \mathrm{mmol} / \mathrm{l}(200 \mathrm{mg} / \mathrm{dl})$, a venous $\mathrm{pH}<7.3$, bicarbonate $<15 \mathrm{mmol} / \mathrm{l}$, with ketonuria and ketones in serum, biochemical criteria agreed by different international societies (ADA, ESPE) $(5,6)$. 
Regarding the annual incidence of ketoacidosis, it is between $4.8 \%$ and $5.2 \%$ in children and young adults (7), while the mortality rate is $6 \%$ to $24 \%$ in developing countries and less than $1 \%$ in developed ones (8). The most severe complication of ketoacidosis is cerebral edema which can occur in about $0.5-1 \%$ of children, with a mortality rate of $20-25 \%$ (9).

With regard to diabetic ketoacidosis, apart from the physiological factors that condition the occurrence of ketoacidosis, there are also some additional risk factors. Small age (under 5 years), female gender, limited access to medical services, as well as unfavorable socio-economic status are discussed $(10,11)$.

Regarding hypoglycemia, it is the main barrier to achieving very good glycemic control, severe hypoglycemia being the greatest fear of patients with diabetes and their parents (12). Depending on serum glucose levels, hypoglycemia may be mild (glycemia values between 54 and $70 \mathrm{mg} / \mathrm{dl}$ ), moderate (glycemia less than $54 \mathrm{mg} / \mathrm{dl}$ ) or severe (when another person's intervention is needed, with blood sugar usually less than 40 $\mathrm{mg} / \mathrm{dl}$ ) (13). Children who have already had a severe hypoglycemic episode in the last 12 months may be included in a risk group.

Among the neurological disorders associated with the acute phase of severe hypoglycemia, we mention transient mental deficit, electroencephalographic abnormalities, regional increase in cerebral blood flow. In patients with repeated severe hypoglycemia, especially in children under 5 years of age, permanent cognitive dysfunction may occur (14).

The paper aims to determine the prevalence of ketoacidosis and severe hypoglycemia in children and adolescents with type 1 diabetes, as well as to figure out the causes and factors favoring these complications.

\section{MATERIALS AND METHODS}

We present the results of a retrospective study conducted between January 2015 - December 2019 on a group of 119 children and adolescents with type 1 diabetes in the records of the Pediatric Diabetology office within the "St. Spiridon“ County Emergency Clinical Hospital from lasi. The data from the dispensary sheets and their treatment notebooks from the last 5 years were analyzed. The mandatory criteria for inclusion in the study were age under 19 years and the duration of disease evolution of at least 1 year. Only the cases with ketoacidosis and severe hypoglycemia that required emergency hospitalization were quantified, aiming to determine the etiology of these complications, as well as to establish correlations with certain parameters: age, gender, environment, age of the disease, insulin therapy regimen used, glycemic balance. The study was conducted according to provisions of the Helsinki Declaration (the local ethics committee approved the study) and all the patients signed the consent for the participation in this study.

\section{SIGNIFICANCE ANALYSIS}

All analyses were performed using SPSS. The ANOVA test, $c^{2}$ test, Kruskall-Wallis and "Pearson" correlation were used. All data are presented as the mean \pm the standard error of the mean. $\mathrm{P}<0.05$ was considered to indicate a statistically significant difference.

\section{RESULTS}

The analysis of socio-demographic characteristics showed a slightly higher frequency of male children $(52.9 \%)$ and from rural areas (54.6\%).

The current age of children varied between 3 years and 7 months and 18 years and 9 months, the average value being slightly higher in males (13.08 vs 12.74 years; $p=0.624)$ and in those from rural areas (13.33 vs. 12.42 years; $p=0.190$ ) (Table 1 ).

The age of children at the onset of the disease ranged from 1 year and 7 months to 17 years and 4 months, with no significant differences in mean age between boys (boys $7.64 \pm 3.71$ vs. girls $7.84 \pm 3.56$ years; $p=0.769$ ).

The age of diabetes varies between 1 and 14.7 years, registering an average value of approximately 5 years in both sexes (M 5.4 years vs $F 4.9$ years;

TABLE 1. The average age of children mean age depending on gender and origin

\begin{tabular}{|c|c|c|c|c|c|c|c|c|}
\hline \multirow{2}{*}{ Characteristics } & \multirow{2}{*}{$\mathrm{N}$} & \multirow{2}{*}{ Mean } & \multirow{2}{*}{$\begin{array}{c}\text { Std. } \\
\text { Deviation }\end{array}$} & \multirow{2}{*}{$\begin{array}{l}\text { Std. } \\
\text { Error }\end{array}$} & \multicolumn{2}{|c|}{$\begin{array}{l}\text { 95\% Confidence Interval } \\
\text { for Mean }\end{array}$} & \multirow{2}{*}{$\begin{array}{l}\text { Min } \\
\text { years }\end{array}$} & \multirow{2}{*}{$\begin{array}{l}\text { Max } \\
\text { years }\end{array}$} \\
\hline & & & & & $\begin{array}{l}\text { Lower } \\
\text { Bound }\end{array}$ & $\begin{array}{l}\text { Upper } \\
\text { Bound }\end{array}$ & & \\
\hline \multicolumn{9}{|l|}{ Sex } \\
\hline Male & 63 & 13.08 & 3.81 & 0.48 & 12.12 & 14.04 & 3.70 & 18.70 \\
\hline Female & 56 & 12.74 & 3.80 & 0.51 & 11.72 & 13.75 & 4.10 & 18.90 \\
\hline \multicolumn{9}{|l|}{ Origin } \\
\hline Urban & 54 & 12.42 & 4.03 & 0.55 & 11.32 & 13.52 & 3.70 & 18.30 \\
\hline Rural & 65 & 13.33 & 3.56 & 0.44 & 12.45 & 14.22 & 6.10 & 18.90 \\
\hline
\end{tabular}


TABLE 2. Duration of disease evolution depending on gender and origin

\begin{tabular}{|c|c|c|c|c|c|c|c|c|}
\hline \multirow{2}{*}{ Characteristics } & \multirow{2}{*}{$\mathrm{N}$} & \multirow{2}{*}{ Mean } & \multirow{2}{*}{$\begin{array}{l}\text { Std. } \\
\text { Deviation }\end{array}$} & \multirow{2}{*}{$\begin{array}{l}\text { Std. } \\
\text { Error }\end{array}$} & \multicolumn{2}{|c|}{$\begin{array}{c}95 \% \text { Confidence Interval } \\
\text { for Mean }\end{array}$} & \multirow{2}{*}{$\begin{array}{l}\text { Min } \\
\text { years }\end{array}$} & \multirow{2}{*}{$\begin{array}{l}\text { Max } \\
\text { years }\end{array}$} \\
\hline & & & & & $\begin{array}{l}\text { Lower } \\
\text { Bound }\end{array}$ & $\begin{array}{l}\text { Upper } \\
\text { Bound }\end{array}$ & & \\
\hline \multicolumn{9}{|l|}{ Sex } \\
\hline Male & 63 & 5.40 & 3.60 & .45 & 4.50 & 6.31 & 1.00 & 14.70 \\
\hline Female & 56 & 4.90 & 2.96 & .40 & 4.11 & 5.70 & 1.00 & 10.30 \\
\hline \multicolumn{9}{|l|}{ Origin } \\
\hline Urban & 54 & 5.25 & 3.06 & 0.42 & 4.41 & 6.09 & 1.00 & 11.50 \\
\hline Rural & 65 & 5.10 & 3.52 & 0.44 & 4.23 & 5.97 & 1.30 & 14.70 \\
\hline
\end{tabular}

TABLE 3. The relationship between HbA1c and age group, age of diabetes, gender, origin

\begin{tabular}{|c|c|c|c|c|c|c|c|c|}
\hline \multirow{2}{*}{ Characteristics } & \multirow{2}{*}{$\mathrm{N}$} & \multirow{2}{*}{ Mean } & \multirow{2}{*}{$\begin{array}{c}\text { Std. } \\
\text { Deviation }\end{array}$} & \multirow{2}{*}{$\begin{array}{l}\text { Std. } \\
\text { Error }\end{array}$} & \multicolumn{2}{|c|}{$\begin{array}{l}95 \% \text { Confidence } \\
\text { Interval for Mean }\end{array}$} & \multirow{2}{*}{$\underset{\%}{\operatorname{Min}}$} & \multirow{2}{*}{$\begin{array}{c}\operatorname{Max} \\
\%\end{array}$} \\
\hline & & & & & $\begin{array}{l}\text { Lower } \\
\text { Bound }\end{array}$ & $\begin{array}{l}\text { Upper } \\
\text { Bound }\end{array}$ & & \\
\hline \multicolumn{9}{|l|}{ Gender } \\
\hline Male & 63 & 8.63 & 1.87 & 0.24 & 8.15 & 9.10 & 5.16 & 15.15 \\
\hline Female & 56 & 9.46 & 2.24 & 0.30 & 8.85 & 10.07 & 5.94 & 16.29 \\
\hline \multicolumn{9}{|l|}{ Origin } \\
\hline Urban & 54 & 9.09 & 2.32 & 0.32 & 8.45 & 9.73 & 5.35 & 16.29 \\
\hline Rural & 65 & 8.96 & 1.89 & 0.24 & 8.49 & 9.43 & 5.16 & 14.41 \\
\hline \multicolumn{9}{|l|}{ Age group } \\
\hline$<13$ years & 52 & 8.80 & 1.67 & 0.23 & 8.33 & 9.26 & 5.35 & 14.41 \\
\hline$\geq 13$ years & 65 & 9.20 & 2.37 & 0.29 & 8.61 & 9.78 & 5.16 & 16.29 \\
\hline \multicolumn{9}{|l|}{ Age of diabetes } \\
\hline$<5$ years & 64 & 9.02 & 1.94 & 0.24 & 8.54 & 9.51 & 5.80 & 15.15 \\
\hline$\geq 5$ years & 53 & 9.02 & 2.27 & 0.31 & 8.39 & 9.64 & 5.16 & 16.29 \\
\hline
\end{tabular}

$p=0.416)$ regardless of the origin ( $U 5.25$ years vs. $R 5.10$ years; $p=0.806$ ) (Table 2 ).

During monitoring, glycosylated hemoglobin (HbA1c) recorded average values ranging from $5.16 \%$ to $16.29 \%$, the mean value being significantly higher in females ( $F 9.46 \%$ vs. M 8.63\% p $=0.031$ ). No significant differences were observed between the means of origin (Urban $9.09 \%$ vs. Rural 8.96\%; $p=0.738$ ), age groups ( $<13$ years $8.80 \%$ vs. $\geq 13$ years $9.20 \% ; p=0.309$ ) or age of diabetes ( $<5$ years $9.02 \%$ vs $\geq 5$ years $9.02 \%$; $\mathrm{p}=0.986$ ) (Table 3).

However, there is a direct correlation, moderate in intensity, between $\mathrm{HbA1}$ c level and child age $(r=+0.277$; $p=0.002), 27.7 \%$ of children having a higher level of $\mathrm{HbA1 \textrm {C }}$ at older ages (Figure 1 ).

The study shows that $28.6 \%$ of patients ( 34 cases) presented severe hypoglycemia, without significant differences in the estimated risk between the sexes (RR $=1 ; p=1,000)$, but with a slightly higher risk in children from urban areas $(\mathrm{RR}=1.25 ; 95 \% \mathrm{Cl}$ : 0.84-1.87; $p=0.315)$ and in those aged over 13 years $(R R=1.14$; 95\% Cl: 0.82-1.59; $p=0.541$ ).

In patients with diabetes for more than 5 years, the estimated risk of severe hypoglycemia was approximately 2 -fold higher $(\mathrm{RR}=1.92 ; 95 \% \mathrm{Cl}: 1.32-2.78$; $\mathrm{p}=0.002$ ) (Table 4).

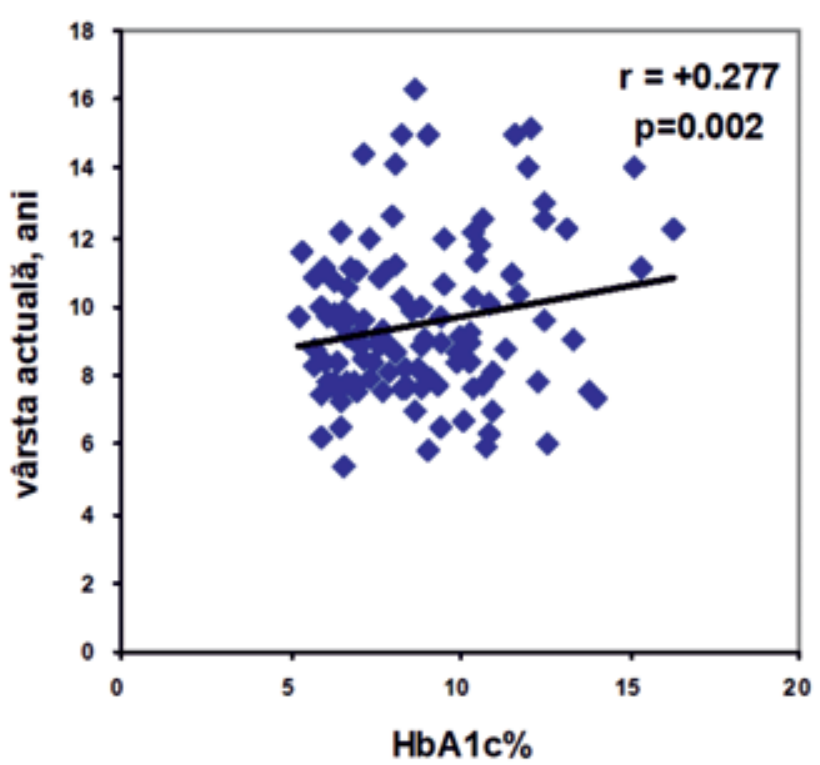

FIGURE 1. The correlation between HbA1c and the child's age

Among the most common causes of severe hypoglycemia is intense physical activity without additional carbohydrate intake in 15 cases, delayed carbohydrate intake in 11 cases, and insulin excess in 8 cases.

Regarding ketoacidosis, it was found in $15.13 \%$ of patients (18 cases), with an estimated risk slightly high- 
er in females ( $R R=1.52 ; 95 \% \mathrm{Cl}: 1.02-2.25 ; p=0.122)$, in those with rural origin ( $\mathrm{RR}=1.28 ; 95 \% \mathrm{Cl}$ : 0.88-1.87; $\mathrm{p}=0.309$ ) and in adolescents aged over 13 years ( $R R=1.34 ; 95 \% \mathrm{Cl}: 0.95-1.87 ; \mathrm{p}=0.199)$. In patients with diabetes for more than 5 years, the estimated risk of ketoacidosis was 1.63-fold higher $(\mathrm{RR}=1.63 ; 95 \% \mathrm{Cl}$ : 1.09-2.43; $p=0.044$ ) (Table 5).

TABLE 4. Statistical significance of the patients with severe hypoglycemia

\begin{tabular}{|c|c|c|c|c|}
\hline & $\begin{array}{l}\text { Patients with } \\
\text { severe hypo- } \\
\text { glycemia }\end{array}$ & $\mathbf{P}$ & RR & IC95\% \\
\hline Male $(n=63)$ & $18(28.6 \%)$ & \multirow{2}{*}{1.000} & 1.00 & 0.69-1.46 \\
\hline Female $(n=56)$ & $16(28.6 \%)$ & & 1.00 & $0.66-1.53$ \\
\hline Urban $(n=54)$ & $18(33.3 \%)$ & \multirow{2}{*}{0.315} & 1.25 & $0.84-1.87$ \\
\hline Rural (n=65) & $16(24.6 \%)$ & & 0.82 & $0.55-1.22$ \\
\hline $\begin{array}{l}\text { Age }<13 \text { years } \\
(n=52)\end{array}$ & $13(25.0 \%)$ & \multirow{2}{*}{0.541} & 0.83 & $0.51-1.35$ \\
\hline $\begin{array}{l}\text { Age } \geq 13 \text { years } \\
(n=67)\end{array}$ & 21 (31.3\%) & & 1.14 & $0.82-1.59$ \\
\hline $\begin{array}{l}\text { Age of diabetes } \\
<5 \text { years }(n=66)\end{array}$ & $11(16.7 \%)$ & \multirow{2}{*}{0.002} & 0.50 & $0.30-0.83$ \\
\hline $\begin{array}{l}\text { Age of diabetes } \\
\geq 5 \text { years }(n=53)\end{array}$ & 23 (43.4\%) & & 1.92 & $1.32-2.78$ \\
\hline
\end{tabular}

TABLE 5. Statistical significance of the patients with ketoacidosis

\begin{tabular}{|c|c|c|c|c|}
\hline & $\begin{array}{l}\text { Patients with } \\
\text { ketoacidosis }\end{array}$ & $\mathbf{P}$ & RR & IC95\% \\
\hline Male $(n=63)$ & $6(9.7 \%)$ & \multirow{2}{*}{0.122} & 0.60 & $0.30-1.17$ \\
\hline Female $(n=56)$ & $12(21.4 \%)$ & & 1.52 & $1.02-2.25$ \\
\hline Urban $(n=54)$ & $6(11.1 \%)$ & \multirow{2}{*}{0.309} & 0.69 & $0.35-1.38$ \\
\hline Rural (n=65) & $12(18.8 \%)$ & & 1.28 & $0.88-1.87$ \\
\hline $\begin{array}{l}\text { Age }<13 \text { years }(n \\
=52)\end{array}$ & $5(9.8 \%)$ & \multirow{2}{*}{0.199} & 0.60 & $0.28-1.31$ \\
\hline $\begin{array}{l}\text { Age } \geq 13 \text { years }(n \\
=67)\end{array}$ & 13 (19.4\%) & & 1.34 & $0.95-1.87$ \\
\hline $\begin{array}{l}\text { Age of diabetes } \\
<5 \text { years }(n=66)\end{array}$ & $6(9.2 \%)$ & \multirow{2}{*}{0.044} & 0.57 & $0.29-1.11$ \\
\hline $\begin{array}{l}\text { Age of diabetes } \\
\geq 5 \text { years }(n=53)\end{array}$ & $12(22.6 \%)$ & & 1.63 & $1.09-2.43$ \\
\hline
\end{tabular}

Among patients with ketoacidosis, $55.55 \%$ (10 cases) had recurrent ketoacidosis, being in $39 \%$ of cases adolescents with a disease duration of more than 5 years, with low adherence to treatment and a precarious glycemic balance. In this regard, the presence of increased glycosylated hemoglobin was observed in all patients with recurrent ketoacidosis, thus demonstrating the link between unsatisfactory glycemic control and the occurrence of ketoacidosis.

In this study, because the majority of patients $87 \%$ (103 cases) followed a basal-bolus treatment regimen, no comparison could be made between the groups on glycemic balance and the frequency of acute metabolic complications depending on insulin treatment. Ketoacidosis was caused in 10 cases (55.5\%) by major devia- tions from diet and additional carbohydrate intake, and in 8 cases $(45.5 \%)$ by the omission of insulin doses. Among the factors favoring the appearance of acute metabolic complications, we also mention psychological disorders, these being identified in 17 patients (14.4\%). Of these, during monitoring, 8 patients $(47.1 \%$; $p=0.005)$ had severe hypoglycemia and 7 patients (41.2\%; $p=0.004)$ ketoacidosis.

\section{DISCUSSIONS}

Taking into consideration all the results we have obtained they can be compared to data from the literature that emphasizes the causal factors on severe hypoglycemia and ketoacidosis. In an 18-month study of a group of 142 children and adolescents with type 1 diabetes, Wysocki et al. reported a $41 \%$ incidence of severe hypoglycemia (15), while Rewers et al. found a frequency of $19 \%$ (16). According to some other data from, it is demonstrated a positive correlation between the age of the disease and hypoglycemia (17) and at the same time a causal relationship between severe hypoglycemia and delayed meals or snacks in $44 \%$ of cases (18).

As we showed in our results, inadequate glycemic control and the occurrence of ketoacidosis are strongly linked. In an international study of 49,859 pediatric patients with type 1 diabetes, Maahs et al. showed an increase in the frequency of ketoacidosis in patients with a $\mathrm{Hb}$ A1c value between $7.5 \%$ and 9\% (19). Regarding the insulin therapy regimen used, the DCCT study showed that intensive insulin therapy (multiple daily insulin injections or an insulin pump) provides better glycemic control than conventional treatment with 2 or 3 injections per day (20). Wei-Yu Chou et al. observed a better value of $\mathrm{Hb} \mathrm{A1c}$ in intensively treated patients than in the conventionally treated group, therefore explaining the low risk for ketoacidosis in patients with intensive insulin therapy. The same authors showed that the risk of ketoacidosis was significantly higher only in patients with $\mathrm{Hb}$ A1c values $\geq 7.5 \%$ (21). Approximately $28 \%-65 \%$ of ketoacidosis occurs due to the omission of insulin doses, which is also the major cause of this complication in patients with type 1 diabetes (22-25). Furthermore, the need for periodic psychological and neurological evaluation is very important in the task of monitoring of type 1 diabetes in children and adolescents $(26,27)$.

\section{CONCLUSIONS}

Managing pediatric patients with type 1 diabetes can be considered a real challenge. Achieving therapeutic goals (immediate and long-term) is mainly influenced by maintaining a euglycemic status, with blood glucose values as close as possible to normal values. 
The diabetic child and adolescent may present, during the evolution of the disease, major variations of serum glucose with the appearance of acute metabolic imbalances, respectively ketoacidosis, and severe hypoglycemia. These are, in most cases, determined by low compliance with the recommended therapeutic means (insulin therapy, specific diet, physical activity, glycemic monitoring) and by the lack of involvement and awareness on the part of the patient. Severe hypoglycemia and ketoacidosis have immediate effects, through the vital prognosis, but also distant effects on the functionality of the nervous system in case of severe hypoglycemia.

In conclusion, it is fundamental to prevent these complications through continuous medical education of diabetic patients and their families.

Conflict of interest: none declared Financial support: none declared

\section{REFERENCES}

1. Streisand R, Monaghan M. Young children with type 1 diabetes: challenges, research, and future directions. Curr Diab Rep. 2014; 14(9):520.

2. Ziegler R, Neu A. Diabetes in Childhood and Adolescence. Dtsch Arztebl Int. 2018; 115(9):146-156.

3. Klingensmith GJ, Tamborlane WV, Wood J, et al. Diabetic ketoacidosis at diabetes onset: still an all too common threat in youth. J Pediatr. 2013;162(2):330-4.e1.

4. Tilinca MC, Nania C, Pal S, Tilinca R, Szabo M, Nemes-Nagy E. Evaluation of Metabolic and Hydroelectrolytic Disturbances in Patients Diagnosed with Diabetic Ketoacidosis. Rev. Chim. 2020; 71(1):239-243.

5. Wolfsdorf J, Glaser N, Sperling MA; American Diabetes Association. Diabetic ketoacidosis in infants, children, and adolescents: A consensus statement from the American Diabetes Association. Diabetes Care. 2006;29(5):1150-1159.

6. Dunger DB, Sperling MA, Acerini $\mathrm{CL}$, et al; European Society for Paediatric Endocrinology; Lawson Wilkins Pediatric Endocrine Society. European Society for Paediatric Endocrinology/Lawson Wilkins Pediatric Endocrine Society consensus statement on diabetic ketoacidosis in children and adolescents. Pediatrics. 2004; 113(2):e133-e140.

7. Karges B, Rosenbauer J, Holterhus PM, et al; DPV Initiative. Hospital admission for diabetic ketoacidosis or severe hypoglycemia in 31,330 young patients with type 1 diabetes. Eur J Endocrinol. 2015; 173(3):341-350.

8. Curtis JR, To T, Muirhead S, Cummings E, Daneman D. Recent trends in hospitalization for diabetic ketoacidosis in Ontario children. Diabetes Care. 2002;25(9):1591-1596.

9. Bialo SR, Agrawal S, Boney CM, Quintos JB. Rare complications of pediatric diabetic ketoacidosis. World J Diabetes. 2015; 6(1):167-174

10. Rosenbloom AL. The management of diabetic ketoacidosis in children. Diabetes Ther. 2010;1(2):103-120.
11. Raghupathy P. Diabetic ketoacidosis in children and adolescents. Indian J Endocrinol Metab. 2015; 19(7)(suppl 1):S55-S57.

12. Driscoll KA, Raymond J, Naranjo D, Patton SR. Fear of Hypoglycemia in Children and Adolescents and Their Parents with Type 1 Diabetes. Curr Diab Rep. 2016;16(8):77.

13. International Hypoglycaemia Study Group. Glucose Concentrations of Less Than 3.0 $\mathrm{mmol} / \mathrm{l}(54 \mathrm{mg} / \mathrm{dl})$ Should Be Reported in Clinical Trials: A Joint Position Statement of the American Diabetes Association and the European Association for the Study of Diabetes. Diabetes Care. 2017; 40(1):155-157.

14. Ryan CM, Becker DJ. Hypoglycemia in children with type 1 diabetes mellitus. Risk factors, cognitive function, and management. Endocrinol Metab Clin North Am. 1999; 28(4):883-900.

15. Wysocki T, Harris MA, Mauras N, et al. Absence of adverse effects of severe hypoglycemia on cognitive function in school-aged children with diabetes over 18 months. Diabetes Care. 2003; 26(4):1100-1105.

16. Rewers A, Chase HP, Mackenzie T, et al. Predictors of acute complications in children with type 1 diabetes. JAMA. 2002; 287(19):2511-2518.

17. Limbert C, Schwingshandl J, Haas J, Roth $\mathrm{R}$, Borkenstein M. Severe hypoglycemia in children and adolescents with IDDM: frequency and associated factors. J Diabetes Complications. 1993;7(4):216-220.

18. Shehadeh N, Kassem J, Tchaban I, et al. High incidence of hypoglycemic episodes with neurologic manifestations in children with insulin dependent diabetes mellitus. J Pediatr Endocrinol Metab. 1998; 11(suppl 1):183-187.

19. Maahs DM, Hermann JM, Holman N, et al; National Paediatric Diabetes Audit and the Royal College of Paediatrics and Child Health, the DPV Initiative, and the T1D Exchange Clinic Network. Rates of diabetic ketoacidosis: international comparison with 49,859 pediatric patients with type 1 diabetes from England, Wales, the U.S., Austria, and Germany. Diabetes Care. 2015; 38(10):1876-1882.

20. Nathan DM, Genuth S, Lachin J, et al; Diabetes Control and Complications Trial Research Group. The effect of intensive treatment of diabetes on the development and progression of long-term complications in insulin-dependent diabetes mellitus. N Engl J Med. 1993;329(14):977-986.

21. Chou WY, Li YR, Chan WK, Chen ST. Association of diabetic ketoacidosis, severe hypoglycemia and glycemic control among children and young adults with type 1 diabetes mellitus treated with premixed versus basal-bolus insulin therapy. Biomed J. 2018;41(6):348-355.

22. Hanas R, Lindgren F, Lindblad B. A 2-yr national population study of pediatric ketoacidosis in Sweden: predisposing conditions and insulin pump use. Pediatr Diabetes. 2009;10(1):33-37.

23. Chiang JL, Kirkman MS, Laffel LM, Peters AL; Type 1 Diabetes Sourcebook Authors. Type 1 diabetes through the life span: a position statement of the American Diabetes Association. Diabetes Care. 2014; 37(7):2034-2054.

24. Burdick J, Chase HP, Slover RH, et al. Missed insulin meal boluses and elevated hemoglobin A1c levels in children receiving insulin pump therapy. Pediatrics. 2004; 113(3 Pt 1):e221-e224.

25. Morris AD, Boyle DI, McMahon AD, Greene SA, MacDonald TM, Newton RW; Medicines Monitoring Unit. Adherence to insulin treatment, glycaemic control, and ketoacidosis in insulin-dependent diabetes mellitus. The DARTS/MEMO Collaboration. Diabetes Audit and Research in Tayside Scotland. Lancet. 1997;350(9090):15051510.

26. White NH. Diabetic ketoacidosis in children. Endocrinol Metab Clin North Am. 2000; 29(4):657-682.

27. Litmanovitch E, Geva R, Rachmiel M. Short and long term neuro-behavioral alterations in type 1 diabetes mellitus pediatric population. World J Diabetes. 2015;6(2):259-270. 